This is the author's final, peer-reviewed manuscript as accepted for publication. The publisher-formatted version may be available through the publisher's web site or your institution's library.

\title{
CO2-induced shift in microbial activity affects carbon trapping and water quality in anoxic bioreactors
}

Matthew F. Kirk, Eugenio F. U. Santillan, Robert A. Sanford, Susan J. Altman

\section{How to cite this manuscript}

If you make reference to this version of the manuscript, use the following information:

Kirk, M. F., Santillan, E. F. U., Sanford, R. A., \& Altman, S. J. (2013). CO2-induced shift in microbial activity affects carbon trapping and water quality in anoxic bioreactors. Retrieved from http://krex.ksu.edu

\section{Published Version Information}

Citation: Kirk, M. F., Santillan, E. F. U., Sanford, R. A., \& Altman, S. J. (2013). CO2induced shift in microbial activity affects carbon trapping and water quality in anoxic bioreactors. Geochimica et Cosmochimica Acta, 122, 198-208.

Copyright: (c) 2013 Elsevier Ltd.

Digital Object Identifier (DOI): doi:10.1016/j.gca.2013.08.018

Publisher's Link: http://www.sciencedirect.com/science/article/pii/S0016703713004626

This item was retrieved from the K-State Research Exchange (K-REx), the institutional repository of Kansas State University. K-REx is available at http://krex.ksu.edu 
3

4

5

6 7

8 9

10

11

12

13

14

15

16

17

18

19

20

21

22

\section{$\mathrm{CO}_{2}$-Induced Shift in Microbial Activity Affects Carbon Trapping and} Water Quality in Anoxic Bioreactors

\author{
Matthew F. Kirk ${ }^{1,4, *}$, Eugenio F. U. Santillan², Robert A. Sanford 3 , Susan J. Altman ${ }^{1}$
}

${ }^{1}$ Geochemistry Department, Sandia National Laboratories, P.O. Box 5800, Albuquerque, NM 871850754, USA

2Jackson School of Geosciences, University of Texas at Austin, 1 University Station C9000, Austin, TX 78712-0254, USA

${ }^{3}$ Department of Geology, University of Illinois, 1301 W. Green St. Urbana, IL 61801, USA

${ }^{4}$ Current address: Department of Geology, Kansas State University, Manhattan, KS 66506-3201, USA

*Corresponding author: matthew.f.kirk@gmail.com, +1 785-532-6724 (office), +1 785-532-5159

(fax)

Submitted to:

Geochimica et Cosmochimica Acta

Initially: March 29, 2013

In revised form: August 9, 2013 


\section{Abstract}

Microbial activity is a potentially important yet poorly understood control on the fate and environmental impact of $\mathrm{CO}_{2}$ that leaks into aquifers from deep storage reservoirs. In this study we examine how variation in $\mathrm{CO}_{2}$ abundance affected competition between $\mathrm{Fe}(\mathrm{III})$ and $\mathrm{SO}_{4}{ }^{2-}$-reducers in anoxic bioreactors inoculated with a mixed-microbial community from a freshwater aquifer. We performed two sets of experiments: one with low $\mathrm{CO}_{2}$ partial pressure $(\sim 0.02 \mathrm{~atm})$ in the headspace of the reactors and one with high $\mathrm{CO}_{2}$ partial pressure $(\sim 1 \mathrm{~atm})$. A fluid residence time of 35 days was maintained in the reactors by replacing one-fifth of the aqueous volume with fresh medium every seven days. The aqueous medium was composed of groundwater amended with small amounts of acetate $(250 \mu \mathrm{M})$, phosphate $(1 \mu \mathrm{M})$, and ammonium $(50 \mu \mathrm{M})$ to stimulate microbial activity. Synthetic goethite $(1 \mathrm{mmol})$ and $\mathrm{SO}_{4}{ }^{2-}(500 \mu \mathrm{M}$ influent concentration) were also available in each reactor to serve as electron acceptors. Results of this study show that higher $\mathrm{CO}_{2}$ abundance increased the ability of Fe(III) reducers to compete with $\mathrm{SO}_{4}{ }^{2-}$-reducers, leading to significant shifts in $\mathrm{CO}_{2}$ trapping and water quality. Mass-balance calculations and pyrosequencing results demonstrate that $\mathrm{SO}_{4}^{2-}$ reducers were dominant in reactors with low $\mathrm{CO}_{2}$ content. They consumed $85 \%$ of the acetate after acetate consumption reached steady state while Fe(III) reducers consumed only $15 \%$ on average. In contrast, Fe(III) reducers were dominant during that same interval in reactors with high $\mathrm{CO}_{2}$ content, consuming at least $90 \%$ of the acetate while $\mathrm{SO}_{4}{ }^{2-}$ reducers consumed a negligible amount $(<1 \%)$. The higher rate of $\mathrm{Fe}(\mathrm{III})$ reduction in the high- $\mathrm{CO}_{2}$ bioreactors enhanced $\mathrm{CO}_{2}$ solubility trapping relative to the low- $\mathrm{CO}_{2}$ bioreactors by increasing alkalinity generation (6X). Hence, the shift in microbial activity we observed was a positive feedback on $\mathrm{CO}_{2}$ trapping. More rapid Fe(III) reduction degraded water quality, however, by leading to high Fe(II) concentration. 
47 Keywords: Geological carbon storage, $\mathrm{CO}_{2}$ leakage, iron reduction, sulfate reduction, microbial

48 reaction rates, groundwater, pyrosequencing

\section{INTRODUCTION}

Carbon capture and geological storage is one option in the range of actions that can be used

52 to help stabilize atmospheric $\mathrm{CO}_{2}$ levels despite anticipated increases in $\mathrm{CO}_{2}$ production (IPCC,

53 2005). The process involves capturing $\mathrm{CO}_{2}$ before it is released to the atmosphere and injecting it

54 into a deep subsurface reservoir (Benson and Cole, 2008). $\mathrm{CO}_{2}$ would be injected at depths $>800 \mathrm{~m}$

55 where it would exist as a buoyant supercritical phase (IPCC, 2005). A low-permeability caprock

56 overlying a storage reservoir is necessary to limit upward migration of supercritical $\mathrm{CO}_{2}$. Over time,

$57 \quad \mathrm{CO}_{2}$ would also be trapped by dissolution into water, formation of minerals, and capillary trapping

58 (Benson and Cole, 2008).

Although this mitigation strategy is promising, leakage of $\mathrm{CO}_{2}$ from storage reservoirs is a major environmental concern because the $\mathrm{CO}_{2}$ can cause reactions that negatively impact water

61 quality in overlying freshwater aquifers. The $\mathrm{CO}_{2}$ could also eventually reach the atmosphere,

62 undermining attempts to limit greenhouse gas accumulation. Potential leakage pathways include

63 faults and fractures, abandoned wells, and diffusive leakage through caprocks (Celia and

64 Nordbotten, 2009; IPCC, 2005). $\mathrm{CO}_{2}$ can negatively affect water quality by lowering $\mathrm{pH}$, causing

65 minerals to dissolve, increasing solute levels, and mobilizing both organic and inorganic

66 contaminants (Apps et al., 2010; Kharaka et al., 2010; Little and Jackson, 2010; Lu et al., 2010; Wang

67 and Jaffe, 2004; Wilkin and Digiulio, 2010; Zheng et al., 2009).

Whereas several studies have examined how $\mathrm{CO}_{2}$ leakage would react chemically with

69 water and minerals in the subsurface, relatively little research has examined how $\mathrm{CO}_{2}$ leakage

70 would affect subsurface microbial processes (Harvey et al., 2013). Filling this knowledge gap is

71 important because microorganisms can strongly influence the physical and chemical properties of 
72 the subsurface. Microbes, for example, can lower the permeability of a porous medium by orders of

73 magnitude (Gerlach and Cunningham, 2010), control the mobility of organic and inorganic

74 contaminants (Lovley, 2001), and drive both mineral dissolution and precipitation (Benzerara et al.,

75 2011; Uroz et al., 2009). As a result, the impact that an increase in $\mathrm{CO}_{2}$ abundance has on subsurface

76

77

78

79

80

81

82

83

84

85

86

87

8
microbial populations will affect the fate of that $\mathrm{CO}_{2}$ and its impact on subsurface water resources. Much of the research on microbial interactions with $\mathrm{CO}_{2}$ has examined how $\mathrm{CO}_{2}$ affects cell survival. High pressure $\mathrm{CO}_{2}$ can kill cells by extracting intracellular materials, disabling enzymes, and causing the release of toxic trace elements from minerals (Bertoloni et al., 2006; Oule et al., 2006; Santillan et al., 2013; Wimmer and Zarevucka, 2010). Numerous studies have shown, however, that microorganisms are capable of colonizing environments with aqueous $\mathrm{CO}_{2}$ concentrations that are high relative to most natural waters (e.g., Inagaki et al., 2006; Oppermann et al., 2010; Videmsek et al., 2009; Yakimov et al., 2002). Hence, microbial communities are capable of withstanding at least moderate increases in $\mathrm{CO}_{2}$ abundance. Cells that have Gram positive cell walls, exist within biofilms, and produce spores appear to be better able to survive exposure to high levels of $\mathrm{CO}_{2}$ (Mitchell et al., 2008; Zhang et al., 2006). Carbonate minerals can also promote cell survival by providing rapid pH buffering (Wu et al., 2010). Although previous research shows that communities can persist following an increase in $\mathrm{CO}_{2}$ abundance, it is unclear whether an increase in $\mathrm{CO}_{2}$ could affect competition between different metabolic groups. In this study, we use bioreactor experiments with periodic fluid replacement to examine how an increase in $\mathrm{CO}_{2}$ affects competition between $\mathrm{Fe}(\mathrm{III})$ and $\mathrm{SO}_{4}{ }^{2-\text {-reducing }}$ microorganisms. Our objectives were to monitor the activity of each group and to assess how microbial activity impacted $\mathrm{CO}_{2}$ trapping and water quality. We focus on these groups of microorganisms because thermodynamic relationships suggest that variation in $\mathrm{CO}_{2}$ abundance would affect them differently. As $\mathrm{pH}$ decreases, the free energy yield of microbial Fe(III) reduction increases rapidly while that of microbial $\mathrm{SO}_{4}{ }^{2-}$ reduction changes little (Bethke et al., 2011; Postma 
97 and Jakobsen, 1996). A decrease in $\mathrm{pH}$ associated with increasing $\mathrm{CO}_{2}$ abundance, therefore, could

98 affect competition between these groups for electron donors (Kirk, 2011). Moreover, these groups

99 of microorganisms are also widespread in subsurface environments (Bethke et al., 2011; Lovley and

100 Chapelle, 1995). Hence, they are likely present in many of the aquifers that could be exposed to $\mathrm{CO}_{2}$

101 leakage.

102

We performed two sets of experiments: one with a $\mathrm{CO}_{2}$ partial pressure of about $0.02 \mathrm{~atm}$ in

103 the headspace of the reactors and one with a $\mathrm{CO}_{2}$ partial pressure of about $1 \mathrm{~atm}$. Hereafter these

104 experiments are referred to as the "low- $\mathrm{CO}_{2}$ " and the "high- $\mathrm{CO}_{2}$ " experiments, respectively.

105 Comparison of the results between these sets of experiments provides a measure of the extent to

106 which variation in $\mathrm{CO}_{2}$ abundance influenced chemistry and microbial activity in our study.

107

108

\section{MATERIALS AND METHODS}

\subsection{Inoculum}

Microorganisms used in the bioreactors were collected during November 2011 from the

111 Mahomet aquifer, a freshwater aquifer in central Illinois (Kempton et al., 1991). Note that

112 microorganisms from the aquifer were not used in an attempt to simulate the aquifer

113 experimentally but rather to seed the bioreactors with a mixed-community of microorganisms that

114 naturally co-exist. The sample was collected as described previously by lowering a sterile bag of

115 aquifer sediment into a well, CHM95A, and allowing it to incubate for 12 months (Flynn et al.,

116 2008). Sediment removed from the bag after the incubation was immediately placed into an

117 anaerobic culture tube (Belco Glass Inc.) completely filled with oxygen-free groundwater collected

118 previously from the aquifer. The tube was then quickly plugged with a butyl-rubber stopper, sealed

119 with an aluminum crimp, and stored for 5 months until use. To limit changes in community

120 composition during storage, the sample was stored in the dark at $4^{\circ} \mathrm{C}$. The extent to which cold

121 storage affected the composition of the microbial community was not evaluated. However, because 
122 the same sample was used to inoculate all of our reactors, any changes that occurred during storage 123 would have affected each set of experiments equally.

124 Well CHM95A was chosen for collection of an inoculum sample for this study because

125 previous research showed that $\mathrm{Fe}(\mathrm{III})$ and $\mathrm{SO}_{4}^{2-}$-reducing microorganisms are active where the well 126 is completed (Flynn et al., 2012). In general, Fe(III) reducers are present throughout the Mahomet 127 aquifer, reflecting the widespread availability of Fe(III) oxyhydroxides, anoxic conditions, and 128 limited availability of nitrate (Flynn et al., 2013; Flynn et al., 2012; Kelly et al., 2005). In addition to $129 \mathrm{Fe}(\mathrm{III})$ reducers, $\mathrm{SO}_{4}{ }^{2-}$ reducers are active where $\mathrm{SO}_{4}{ }^{2-}$ concentration exceeds about $0.03 \mathrm{mM}$ and 130 methanogens, where $\mathrm{SO}_{4}{ }^{2-}$ concentration falls below that level (Flynn et al., 2013; Flynn et al., 131 2012). Groundwater from CHM95A contains about $0.14 \mathrm{mM} \mathrm{SO}_{4}^{2-}$ (Burch, 2008; Flynn et al., 2012), 132 consistent with previous detection of both $\mathrm{Fe}\left(\mathrm{III}\right.$ and $\mathrm{SO}_{4}{ }^{2-}$ reducers there.

\subsection{Groundwater medium}

Groundwater from the Mahomet aquifer was used to make aqueous medium for the experiment, helping to limit the extent to which culturing effects would have limited growth of cells. The water was collected one year prior to the experiment from well CHM95D. The well produces water with similar bulk composition to that from CHM95A, which is located about $27 \mathrm{~km}$ away (Burch, 2008). Previous workers have found little nitrate $(<1 \mu \mathrm{M})$ in groundwater from the well (Burch, 2008; Flynn et al., 2012). During storage at $4^{\circ} \mathrm{C}$ prior to the experiment, however, a small concentration of nitrate had accumulated in the water presumably from ammonium oxidation. The water initially contained about $57 \mu \mathrm{M}$ ammonium. We removed the nitrate before the experiment using a sorbent material (Nitra-Zorb ${ }^{\mathrm{TM}}$, API).

Following nitrate removal, the groundwater was amended with sodium acetate $(250 \mu \mathrm{M})$, monopotassium phosphate $(1 \mu \mathrm{M})$, and ammonium chloride $(50 \mu \mathrm{M})$ to stimulate microbial activity.

146 We also added sodium $\mathrm{SO}_{4}{ }^{2-}(500 \mu \mathrm{M})$ to potentially support growth of $\mathrm{SO}_{4}^{2-}$ reducers present in the 
147 inoculum. Addition of $\mathrm{SO}_{4}{ }^{2-}$ was necessary because, unlike well CHM95A, groundwater from

148 CHM95D contained little $\mathrm{SO}_{4}{ }^{2-}(<10 \mu \mathrm{M})$. Acetate, the electron donor used by microbes in the 149 experiment, was not added to groundwater used in abiological (control) experiments to help 150 ensure that they remained sterile throughout the study. The amount added to the medium used for 151 biologically-active reactors is higher than that typically observed in natural aquifers. Acetate 152 concentrations in coastal plain aquifers, for example, range up to about $30 \mu \mathrm{M}$ (McMahon and 153 Chapelle, 1991). However, once acetate consumption reached steady state during the experiments, 154 the maximum concentration of acetate in the reactors at any given time was $50 \mu \mathrm{M}$, a value similar 155 to that observed in coastal plain aquifers.

156 After amendments were added, $100 \mathrm{~mL}$ of the medium was dispensed into $160 \mathrm{~mL}$ serum 157 bottles (Wheaton) and purged for $1 \mathrm{~h}$ to remove oxygen. The purge gas consisted either entirely of $158 \mathrm{CO}_{2}$ (medium for high- $\mathrm{CO}_{2}$ reactors; $\sim 1 \mathrm{~atm} \mathrm{PCO}_{2}$ ) or nitrogen containing $2 \% \mathrm{CO}_{2}$ (medium for low$159 \mathrm{CO}_{2}$ reactors; $\sim 0.02 \mathrm{~atm} \mathrm{PCO}_{2}$ ). After purging, the bottles were stoppered and sealed as described 160 above, autoclaved for 20 minutes at $121^{\circ} \mathrm{C}$, and stored at room temperature $\left(\sim 22^{\circ} \mathrm{C}\right)$ until they 161 were used to replenish fluids removed from the reactors during the experiment, as described 162 below. The final composition of the groundwater medium is provided in the Electronic Annex 163 (Table EA1).

\subsection{Bioreactors}

Each set of bioreactor experiments was performed in duplicate: (1) biologically-active and

167 control (abiological) reactors containing high- $\mathrm{CO}_{2}$ medium and (2) biologically-active and control

168 reactors containing low- $\mathrm{CO}_{2}$ medium. The reactors consisted of $160 \mathrm{~mL}$ serum bottles containing $169100 \mathrm{~mL}$ of groundwater medium and $1 \mathrm{mmol}$ of goethite $(\alpha-\mathrm{FeOOH})$, which provided a source of 170 Fe(III) for Fe(III) reducers. Preparation and identification of the goethite was described previously 
171 (Kirk et al., 2010). Aquifer sediment was not included because the experiments were intended to

172 isolate the interaction between microbes and $\mathrm{CO}_{2}$.

173 Each reactor was plugged with a butyl rubber stopper penetrated by a 4 inch stainless-steel

174 needle (Popper), which was used for fluid exchanges during the experiment. The needle was

175 capped with a gas-tight syringe valve (VICI Precision Sampling) to prevent gas leakage. After the

176 reactors were fully assembled, we sterilized them by autoclaving for 20 minutes at $121^{\circ} \mathrm{C}$ and then

177 purged them through the 4 inch needle with filter-sterilized $\mathrm{CO}_{2}$ or $2 \% \mathrm{CO}_{2}$ in nitrogen. Hence, the

178 initial fluid in the reactors had a composition equivalent to the high- $\mathrm{CO}_{2}$ medium or the low- $\mathrm{CO}_{2}$

179 medium. During purging, each septum was also penetrated with a second needle that extended into

180 the reactor headspace and allowed purge gas to escape.

181 After the reactor solutions were purged and cooled to room temperature, they were

182 inoculated with $1 \mathrm{~mL}$ of solution from the CHM95A microbe sample. The sample was vortexed for

18330 seconds prior to withdrawing inoculum to dislodge cells from sediment surfaces. The inoculum

184 injected into the control reactors had been sterilized prior to injection by autoclaving 3 times with

185 at least $48 \mathrm{~h}$ between sterilizations.

186 Following incubation for 1 week and every seventh day thereafter, one-fifth (20 mL) of the

187 aqueous volume of each reactor was removed through the fixed needle without disturbing reactor

188 solids. Effluent was withdrawn with a $20 \mathrm{~mL}$ syringe (BD), which was sealed with a syringe valve

189 (Cole-Parmer) and used for short-term storage until the water could be analyzed. Lastly, the

190 volume withdrawn was immediately replaced with $20 \mathrm{~mL}$ of fresh medium using a syringe and the

191 reactor was gently mixed. This schedule of medium delivery equates to a fluid residence time of 35

192 days. The reactors incubated in the dark at room temperature during the experiment. 
Precision and detection limits of chemical analyses are summarized in the Electronic Annex

196 (Table EA2). Chemical analysis of effluent samples was performed each week. Fe(II) concentration 197 was measured in effluent samples using the ferrozine method (Stookey, 1970) with a Varian Cary 19850 UV-Vis spectrophotometer. Total alkalinity was measured using Gran alkalinity titrations with $1990.02 \mathrm{~N}$ sulfuric acid and a Thermo Orion 410A+ pH meter with a Cole Parmer pH electrode. Acetate, 200 phosphate, and $\mathrm{SO}_{4}{ }^{2-}$ concentration was measured in $0.45 \mu \mathrm{m}$ filtered samples using a Dionex ICS2011100 ion chromatograph (IC) with an IonPac ${ }^{\circledR}$ AS23 column. Fe(II) and alkalinity analyses were 202 performed immediately after the samples were collected. IC analysis was typically carried out on 203 samples stored overnight at $4^{\circ} \mathrm{C}$.

204 Groundwater medium was periodically analyzed using the same procedures used for 205 reactor effluent. In addition to those methods, four samples were also analyzed for major cation 206 concentrations $\left(\mathrm{Na}^{+}, \mathrm{K}^{+}, \mathrm{Mg}^{2+}, \mathrm{Ca}^{2+}\right)$ using a Perkin Elmer AAnalyst 200 atomic absorption 207 spectrometer (AAS) and Perkin Elmer Optima 8000 inductively coupled plasma optical emission 208 spectrometer (ICP OES).

The acid volatile sulfide (AVS) content of the reactors was measured in samples collected at 210 the end of the experiment to gauge the extent of sulfide mineralization. The analysis was performed 211 as described by Kirk et al. (2010), by reacting fresh, well-mixed bioreactor samples with a

212 hydrochloric acid solution and measuring sulfide concentration using the methylene blue method 213 (Eaton et al., 1995).

\subsection{Microbial community analysis}

We collected samples for microbial community analysis at the end of the experiment by

217 shaking the reactors to thoroughly mix them and then immediately withdrawing fluid. By this

218 approach, the samples contained both water and solids. Total community DNA was extracted from 219 the samples using an Ultraclean® Microbial DNA Isolation Kit (MO BIO). We performed the 
220 extraction using the "Alternative Lysis Method" described by the manufacturer to limit DNA 221 shearing.

222 16S rRNA genes in the extract were amplified and sequenced at a commercial laboratory 223 (MR DNA ${ }^{\mathrm{TM}}$ ). PCR amplification was performed using universal bacterial primers $27 \mathrm{~F}$

224 (AGRGTTTGATCMTGGCTCAG) and 519R (GTNTTACNGCGGCKGCTG) with HotStarTaq Plus Master 225 Mix (Qiagen, Valencia, CA). The reactions were held $94^{\circ} \mathrm{C}$ for 3 minutes, followed by 28 cycles of $22694^{\circ} \mathrm{C}$ for 30 seconds, $53^{\circ} \mathrm{C}$ for 40 seconds, and $72^{\circ} \mathrm{C}$ for 1 minute. Following the last cycle, a final 227 elongation step at $72^{\circ} \mathrm{C}$ for 5 minutes was performed. After PCR, amplicon pyrosequencing 228 (bTEFAP) as described by Dowd et al. (2008) was used to sequence 16S rRNA genes. Amplicon 229 products from different samples were mixed in equal proportion and purified using AMPure® 230 beads (Agencourt Bioscience Corporation). Samples were sequenced using a Roche 454 FLX 231 titanium instrument and reagents according to manufacturer guidelines. We processed the sequence data using QIIME (Caporaso et al., 2010). The program used 233 AmpliconNoise (Quince et al., 2011) to remove primers, barcodes, low-quality reads, and chimeras 234 from the sequences. After this step, 10,479 sequences remained (1767 and 2007 from the high- $\mathrm{CO}_{2}$ 235 reactors and 3545 and 3160 from the low- $\mathrm{CO}_{2}$ reactors) averaging $352 \mathrm{bp}$ (st. dev. 56.3) in length. 236 QIIME then defined Operational Taxonomic Units (OTUs) at 97\% sequence similarity using UCLUST 237 (Edgar, 2010). Taxonomic classification was carried out on representative sequences from each 238 OTU using the Ribosomal Database Project classifier (Wang et al., 2007) (v. 2.2) with an 80\% 239 confidence threshold.

241 2.6. Mass-balance and thermodynamic calculations

Rates of acetate oxidation and $\mathrm{Fe}(\mathrm{III})$ and $\mathrm{SO}_{4}{ }^{2-}$ reduction were evaluated using mass-

243 balance calculations as described previously (Bethke et al., 2011; Kirk et al., 2010). A detailed

244 description of those calculations is available in the Electronic Annex. Chemical activities and 
245 mineral saturation indexes were calculated using The Geochemists Workbench® software, version

246 8.0.10, and the LLNL (Lawrence Livermore National Laboratory) thermodynamic database (Delany 247 and Lundeen, 1990). The software calculated activities using an extended form of the Debye-Hückel 248 equation, the $B$-dot equation (Helgeson, 1969), which is appropriate for solutions with low ionic 249 strength such as the groundwater medium ( $\mathrm{I}<0.02$ molal). To examine whether thermodynamic controls could have affected the rate of Fe(III) and $251 \mathrm{SO}_{4}^{2-}$ reduction in the bioreactors, we calculated how much energy was available $\left(\Delta G_{A}\right)$ to drive the 252 reactions forward. Net metabolic reactions for acetate-consuming $\mathrm{Fe}(\mathrm{III})$ and $\mathrm{SO}_{4}{ }^{2-}$ reducers can be 253 expressed as follows:

$$
8 \mathrm{FeOOH}+15 \mathrm{H}^{+}+\mathrm{CH}_{3} \mathrm{COO}^{-} \rightarrow 2 \mathrm{HCO}_{3}^{-}+12 \mathrm{H}_{2} \mathrm{O}+8 \mathrm{Fe}^{2+}
$$

$$
\mathrm{SO}_{4}^{2-}+\mathrm{CH}_{3} \mathrm{COO}^{-} \rightarrow 2 \mathrm{HCO}_{3}^{-}+\mathrm{HS}^{-}
$$

where goethite provides the source of Fe(III) for Fe(III) reducers. $\Delta G_{A}$ for each group is the negative of the free energy change $\left(\Delta G_{r}\right)$ of each group's net metabolic reaction (Bethke et al., 2011):

$$
\Delta G_{A}=-\Delta G_{r}=-\left[\Delta G_{T}^{\circ}+R T \ln \prod_{i}\left(\gamma_{i} \times m_{i}\right)^{v_{i}}\right]
$$

264 Where $\Delta G^{\circ}{ }_{T}$ is the standard Gibbs free-energy change for reaction $r$ at temperature $T\left({ }^{\circ} \mathrm{K}\right), R$ represents the gas constant $\left(\mathrm{kJ} \cdot \mathrm{mol}^{-1} \cdot \mathrm{K}^{-1}\right), \gamma_{\mathrm{i}}$ and $m_{\mathrm{i}}$ are the activity coefficient $\left(\mathrm{molal}^{-1}\right)$ and molality of the $i$ th chemical species in the reaction, and $v_{\mathrm{i}}$ is the stoichiometric coefficient of that species, 
267 which is positive for products and negative for reactants. $\Delta G^{\circ}{ }_{T}$ values were calculated using The

268 Geochemists Workbench® software and the LLNL dataset.

269 Where acetate content was below detection $(<19 \mu \mathrm{M})$, we report $\Delta G_{A}$ values consistent with 270 that detection limit and describe them as maximum possible values. The reaction for each group 271 was written in terms of the consumption of one acetate. As such, the relative values of $\Delta G_{A}$ we 272 calculated retain some absolute meaning (Bethke et al., 2011). In a single reactor where $\leq 50 \mathrm{~kJ} \mathrm{~mol}^{-}$

$273{ }^{1}$ of energy is available for one group and only $\leq 20 \mathrm{~kJ} \mathrm{~mol}^{-1}$ for another, for example, the first group 274 would actually see $30 \mathrm{~kJ} \mathrm{~mol}^{-1}$ more energy than the second because inserting an actual acetate 275 concentration in the calculation would change $\Delta \mathrm{G}_{\mathrm{A}}$ values for each group by an equivalent amount.

276 For comparisons made between reactors, the possibility that acetate levels differ by up to $19 \mu \mathrm{M}$ 277 adds uncertainty, but the uncertainty is small because, written in terms of one acetate, the $\Delta G_{A}$ of 278 the reactions does not vary strongly with acetate content. All else being equal, for example, if 279 acetate content differed by $19 \mu \mathrm{M}$ between two of the reactors, the $\Delta G_{A}$ of Fe(III) reduction in each 280 would only differ by $7 \mathrm{~kJ} \mathrm{~mol}^{-1}$.

\section{3. RESULTS AND DISCUSSION}

\section{3.1. Aqueous chemistry}

The chemical composition of effluent differed considerably between the high- and low- $\mathrm{CO}_{2}$ 285 reactors, reflecting differences in $\mathrm{CO}_{2}$ abundance as well as microbial reaction rates. Consistent with $\mathrm{CO}_{2}$ partial pressures, the pH of effluent from the high- and low- $\mathrm{CO}_{2}$ control reactors averaged

2875.72 and 7.21, respectively, throughout the experiment (Fig. 1). The pH of effluent from the

288 biologically-active low- $\mathrm{CO}_{2}$ reactors did not vary significantly from the $\mathrm{pH}$ of corresponding control 289 reactors $(\mathrm{P}=0.13$; Student's t-test $)$. The $\mathrm{pH}$ of effluent from the biologically-active high- $\mathrm{CO}_{2}$ 290 reactors, however, did diverge significantly from control $\mathrm{pH}(\mathrm{P}<0.0001)$. Initially near control 
291 levels, the $\mathrm{pH}$ of effluent from both high- $\mathrm{CO}_{2}$ reactors increased and ultimately stabilized at an 292 average of 5.92 over the final 50 days of the experiment.

293 This shift in pH occurred simultaneously with changes in effluent acetate, alkalinity, Fe(II),

294 and $\mathrm{SO}_{4}^{2-}$ concentration in the biologically-active reactors (Fig. 1). Acetate content fell from an 295 average of $0.27 \mathrm{mM}$ to values near or below the detection limit ( $19 \mu \mathrm{M}$ ) by 50 days into the 296 experiment in both sets of reactors. Alkalinity increased from $4.8 \mathrm{meq} \mathrm{L}^{-1}$ to an average of $8.4 \mathrm{meq}$ $297 \mathrm{~L}^{-1}$ and 5.4 meq L-1 during the second half of the experiment in the high- and low- $\mathrm{CO}_{2}$ reactors, 298 respectively, and Fe(II) content increased from below detection $(<1.5 \mu \mathrm{M})$ to an average of $1.62 \mathrm{mM}$ 299 and $0.13 \mathrm{mM}$, respectively. $\mathrm{SO}_{4}{ }^{2-}$ concentration decreased from $0.47 \mathrm{mM}$ to $0.30 \mathrm{mM}$ by the end of 300 the experiment in the low- $\mathrm{CO}_{2}$ reactors but was not significantly different from control values in the 301 high- $\mathrm{CO}_{2}$ reactors $(\mathrm{P}=0.37)$.

These changes in aqueous chemistry are consistent with growth of $\mathrm{Fe}(\mathrm{III})$ - and $\mathrm{SO}_{4}{ }^{2-}$ reducing microorganisms. Within the first two weeks of the experiment, the decrease in effluent acetate and $\mathrm{SO}_{4}{ }^{2-}$ levels and the increase in $\mathrm{Fe}(\mathrm{II})$ and alkalinity content indicate populations of both groups began to grow. Stabilization of effluent acetate content near or below the detection limit during the final 50 days of the experiment indicates that populations in both sets of reactors had 307 grown enough to consume nearly all of the influent acetate each week. consumed an average of only $15 \%$ of the acetate supply each week while $\mathrm{SO}_{4}{ }^{2-}$ reducers consumed

$31485 \%$. The sum of acetate consumption by Fe(III) and $\mathrm{SO}_{4}{ }^{2-}$ reduction does not total $100 \%$ for the 315 high- $\mathrm{CO}_{2}$ reactors possibly because the values are averages over time and between duplicate 
reactors. Adsorption of Fe(II) to surfaces within the reactors may have also contributed to this discrepancy by causing the rate of Fe(III) reduction to be underestimated (see description of massbalance calculations in Electronic Annex). Nonetheless, the results of the calculation provide strong evidence that higher $\mathrm{CO}_{2}$ abundance increased the ability of $\mathrm{Fe}(\mathrm{III})$ reducers to compete with $\mathrm{SO}_{4}{ }^{2-}$ reducers in the reactors.

\subsection{Microbial community composition}

Results from analysis of $16 \mathrm{~S}$ rRNA genes obtained from each reactor are consistent with the mass-balance calculations (Fig. 3). Lineages that contain organisms capable of using Fe(III) as their electron acceptor were present in the samples from both sets of reactors. In high- $\mathrm{CO}_{2}$ reactor samples, an average of $25 \%$ and $24 \%$ of the sequences grouped within Geobacteraceae and Mухососсасеаe, respectively, which contain groups capable of dissimilatory Fe(III) reduction such as Geobacter (Lonergan et al., 1996) and Anaeromyxobacter (Treude et al., 2003), respectively. In samples from the low- $\mathrm{CO}_{2}$ reactors, few sequences grouped within Myxococcaceae $(<1 \%)$ but sequences grouping within Geobacteraceae accounted for $22 \%$ of the sequences on average. Hence, sequences from groups containing organisms capable of Fe(III) reduction were abundant in all four biologically-active reactors but more than twice as abundant in the high- $\mathrm{CO}_{2}$ reactor samples as the low- $\mathrm{CO}_{2}$ reactor samples on average.

Also consistent with the mass-balance calculations, $\mathrm{SO}_{4}{ }^{2-}$ reducing groups were much more abundant in the low- $\mathrm{CO}_{2}$ reactors than the high- $\mathrm{CO}_{2}$ reactors (Fig. 3). Sequences grouping in families with organisms that commonly use $\mathrm{SO}_{4}{ }^{2-}$ as their electron acceptor [Desulfobulbaceae, Desulfovibrionaceae, Desulfuromonadaceae, Desulfobacteraceae, Syntrophaceae, and Syntrophobacteraceae (Garrity et al., 2005)] accounted for an average of $20 \%$ of the sequences in low- $\mathrm{CO}_{2}$ reactor samples but were nearly absent in high- $\mathrm{CO}_{2}$ reactor samples $(<1 \%)$. 
The microbial community we observed in the low- $\mathrm{CO}_{2}$ reactors is similar to that observed in

341 the aquifer used as a source of inoculum and groundwater. As noted above, Fe(III) and $\mathrm{SO}_{4}{ }^{2-}$

342 reducers coexist in the aquifer where $\mathrm{SO}_{4}{ }^{2-}$ is sufficiently available, a relationship also observed in

343 many other anoxic environments (Postma and Jakobsen, 1996). Like the low- $\mathrm{CO}_{2}$ reactors,

344 furthermore, $\delta$-Proteobacteria are common in the aquifer (Flynn et al., 2013; Flynn et al., 2012).

345 In contrast, the abundance of sequences from the high- $\mathrm{CO}_{2}$ reactors that grouped in

346 Myхососсасеae is unlike the Mahomet aquifer. This difference may reflect a preference of Fe(III)-

347 reducing Anaeromyxobacter species for growth at acidic $\mathrm{pH}$, as indicated by previous research

348 (Petrie et al., 2003; Thomas et al., 2009). Whereas the $\mathrm{pH}$ of water in the high- $\mathrm{CO}_{2}$ reactors was

349 acidic, the $\mathrm{pH}$ of Mahomet aquifer groundwater is typically slightly basic (Flynn et al., 2012).

350

351

\subsection{Controls on reaction rates}

The results of our thermodynamic calculations demonstrate that variation in $\Delta G_{A}$ may have

353 contributed to differences in reaction rates between each set of reactors. Values of $\Delta G_{A}$ we

354 calculated differed considerably between the high- and low- $\mathrm{CO}_{2}$ reactors for $\mathrm{Fe}(\mathrm{III})$ reduction but

355 varied little between each set of reactors for $\mathrm{SO}_{4}{ }^{2-}$ reduction (Fig. 4). $\Delta G_{A}$ for Fe(III) reduction was a

356 maximum of $114 \mathrm{~kJ} \mathrm{~mol}^{-1}$ on average over the final 50 days in the high- $\mathrm{CO}_{2}$ reactors compared to

357 only a maximum of $60 \mathrm{~kJ} \mathrm{~mol}-1$ in the low- $\mathrm{CO}_{2}$ reactors. During that same interval, $\Delta G_{A}$ for $\mathrm{SO}_{4}{ }^{2-}$

358 reduction was a maximum of $65 \mathrm{~kJ} \mathrm{~mol}^{-1}$ and $62 \mathrm{~kJ} \mathrm{~mol}-1$ on average in the high- and low- $\mathrm{CO}_{2}$

359 reactors, respectively.

360 The lack of variation in $\Delta G_{A}$ for $\mathrm{SO}_{4}{ }^{2-}$ reduction indicates that thermodynamic controls did

361 not directly cause variation in $\mathrm{SO}_{4}^{2-}$ reduction rates between each set of reactors. Variation in $\Delta G_{A}$

362 for Fe(III) reduction, however, is consistent with thermodynamic controls as a cause of variation. A

363 series of studies by Jin and Bethke $(2002,2003,2005,2007,2009)$ has shown that energy available

364 for a microbial reaction can be a dominant control on the rate at which that reaction can occur. 
365 Those authors found that, where $\Delta G_{A}$ is high relative to the amount of energy conserved by a cells 366 metabolism, thermodynamic controls do not directly limit reaction rates. Where $\Delta G_{A}$ approaches

367 the amount conserved, however, rates grow increasingly limited by thermodynamic controls.

368 Fe(III) reduction may have occurred more rapidly in the high- $\mathrm{CO}_{2}$ reactors than the low- $\mathrm{CO}_{2}$

369 reactors, therefore, because $\Delta G_{A}$ was higher in the high- $\mathrm{CO}_{2}$ reactors. Although $\Delta G_{A}$ for $\mathrm{SO}_{4}^{2-}$

370 reducers varied little, furthermore, an increase in the ability of Fe(III) reducers to compete for

371 acetate as a result of their increase in $\Delta G_{A}$ may explain the low level of $\mathrm{SO}_{4}^{2-}$ reduction in the high-

$372 \quad \mathrm{CO}_{2}$ reactors.

373 Variation in $\Delta G_{A}$ for each group is consistent with the relationship between free energy and

$374 \mathrm{pH}$ noted in the Introduction. The energy yield of microbial Fe(III) reduction increases sharply as

$375 \mathrm{pH}$ decreases because the reaction consumes a large number of protons (equation 1). As such, the

376 reaction was much more favorable at the lower $\mathrm{pH}$ of the high- $\mathrm{CO}_{2}$ reactors than the near-neutral

$377 \mathrm{pH}$ of the low- $\mathrm{CO}_{2}$ reactors. In contrast, the energy yield of $\mathrm{SO}_{4}{ }^{2-}$ reduction varies little with $\mathrm{pH}$

378 because the reaction consumes few protons (equation 2). $\Delta G_{A}$ for $\mathrm{SO}_{4}{ }^{2-}$ reduction varied little

379 between each set of reactors. $\mathrm{CO}_{2}$ may have influenced reaction rates in the bioreactors not by 380 causing variation in the concentration of dissolved inorganic carbon species, therefore, but by 381 affecting $\mathrm{pH}$.

382 The observed variation in the balance between $\mathrm{Fe}(\mathrm{III})$ and $\mathrm{SO}_{4}{ }^{2-}$-reduction with $\mathrm{pH}$ is 383 consistent with the findings of Postma and Jakobsen (1996). Based on a thermodynamic analysis 384 and geochemical evidence from multiple field sites, they concluded that $\mathrm{Fe}(\mathrm{III})$ reduction and $\mathrm{SO}_{4}{ }^{2-}$ 385 reduction may proceed simultaneously over a wide range of conditions but that Fe(III) reduction is 386 favored at acidic $\mathrm{pH}$. In general, however, many factors besides thermodynamics can affect the rate 387 of a microbial reaction, including the abundance of cells and the kinetics of electron donation and 388 acceptance (Jin and Bethke, 2007). In addition to affecting $\Delta G_{A}$, a lower $\mathrm{pH}$ caused by $\mathrm{CO}_{2}$ could have 389 also affected reaction rates by influencing cell physiology. Cells have a pH range within which 
390 growth is possible and usually an optimum $\mathrm{pH}$, at which growth rates are maximized (Madigan et

391 al., 2003). Hence, $\mathrm{CO}_{2}$-driven shifts in $\mathrm{pH}$ away from the $\mathrm{pH}$ optima may have contributed to

392 differences in reaction rates. Moreover, the toxic effects imposed by $\mathrm{CO}_{2}$ itself, as discussed in the

393 Introduction, may have also contributed to variation in reaction rates if the Fe(III) reducers in the

394 experiment were less sensitive to $\mathrm{CO}_{2}$ toxicity than the $\mathrm{SO}_{4}{ }^{2-}$ reducers. Additional research is

395 warranted to fully examine the influence of $\mathrm{CO}_{2}$ on thermodynamic and kinetic controls on

396 microbial reaction rates as well as the extent to which different groups of microorganism are

397 sensitive to its toxic effects.

398

399

400

401

402

403

404 metabolic reaction for Fe(III) reducers (1) illustrates this relationship:

\subsection{Impact on $\mathrm{CO}_{2}$ trapping} bicarbonate:

$$
\mathrm{CO}_{2}(a q)+\mathrm{H}_{2} \mathrm{O} \rightarrow \mathrm{H}^{+}+\mathrm{HCO}_{3}^{-}
$$

Solubility trapping occurs when $\mathrm{CO}_{2}$ dissolves into pore water. The amount that can dissolve varies directly with the partial pressure of $\mathrm{CO}_{2}$. More $\mathrm{CO}_{2}$ was trapped within the aqueous phase of the high- $\mathrm{CO}_{2}$ reactors than the low- $\mathrm{CO}_{2}$ reactors, therefore, because more $\mathrm{CO}_{2}$ was present in the headspace of the high- $\mathrm{CO}_{2}$ reactors. Differences in the amount of inorganic carbon stored in solution widened, however, as a result of the high rate of $\mathrm{Fe}(\mathrm{III})$ reduction in the high- $\mathrm{CO}_{2}$ reactors.

Because Fe(III) reduction consumes a large number of protons (equation 1), the reaction can generate a large amount of carbonate alkalinity by driving conversion of dissolved $\mathrm{CO}_{2}$ into

Where this occurs, additional $\mathrm{CO}_{2}$ can then dissolve in place of that converted to alkalinity, thereby increasing the amount of inorganic carbon stored in solution. Combining equation (4) with the net 


$$
\mathrm{CH}_{3} \mathrm{COO}^{-}+8 \mathrm{FeOOH}+15 \mathrm{CO}_{2}(\mathrm{aq})+3 \mathrm{H}_{2} \mathrm{O} \rightarrow 17 \mathrm{HCO}_{3}^{-}+8 \mathrm{Fe}^{2+}
$$

Comparing (5) to the equation listed above for sulfate reduction (2), we see that Fe(III) reduction can generate up to 8 times more carbonate alkalinity than $\mathrm{SO}_{4}{ }^{2-}$ reduction per mole of acetate oxidized. Although microbial activity increased carbonate alkalinity in both sets of reactors, therefore, solubility trapping was enhanced to a greater extent in the high- $\mathrm{CO}_{2}$ reactors because they hosted more rapid Fe(III) reduction.

The increase in alkalinity that occurred in the high- $\mathrm{CO}_{2}$ reactors was 6 times greater than that in the low- $\mathrm{CO}_{2}$ reactors, a value similar to that predicted by the stoichiometry above. Differences between these values may reflect variation in aqueous speciation. Writing $\mathrm{SO}_{4}{ }^{2-}$ reduction in terms of dihydrogen sulfide instead of bisulfide causes the reaction to yield an additional mole of alkalinity per mole of acetate consumed. Moreover, additional reactions occurring in the experiment besides Fe(III) reduction and $\mathrm{SO}_{4}{ }^{2-}$ reduction may have also affected alkalinity, including mineral precipitation and surface complexation.

In addition to impacting solubility trapping, saturation state calculations show that the shift toward a higher rate of $\mathrm{Fe}(\mathrm{III})$ reduction also favored enhanced mineral trapping of $\mathrm{CO}_{2}$. Mineral trapping occurs where carbonate ions form from $\mathrm{CO}_{2}$ and precipitate as a carbonate mineral such as siderite $\left(\mathrm{FeCO}_{3}\right)$ or calcite $\left(\mathrm{CaCO}_{3}\right)$. Precipitation of calcite was unfavorable on average in both sets of reactors (Fig. 5). The average saturation index $(\log Q / K)$ of calcite over the last 50 days of the experiment was -1.1 and -0.1 in the high- and low- $\mathrm{CO}_{2}$ reactors, respectively. Increases in $\mathrm{pH}, \mathrm{Fe}(\mathrm{II})$, and alkalinity levels caused by microbial activity, however, caused siderite to become supersaturated within the first two weeks in both sets of reactors. The average saturation index of siderite over the last 50 days was 0.9 and 0.8 in the high- and low- $\mathrm{CO}_{2}$ reactors, respectively. While siderite was supersaturated in both sets of experiments, given enough time, more siderite may have formed in the high- $\mathrm{CO}_{2}$ experiments because more $\mathrm{Fe}(\mathrm{II})$ and bicarbonate alkalinity were available. 
Based on our mass-balance calculations, 5 times more $\mathrm{Fe}(\mathrm{II})$ was produced in the high- $\mathrm{CO}_{2}$ reactors as the low- $\mathrm{CO}_{2}$ reactors.

We have no direct evidence that siderite formed in our reactors. It is certainly possible that none did considering that siderite precipitation occurs slowly at room temperature (Jimenez-Lopez and Romanek, 2004). Nonetheless, it is useful to note this shift in the potential for siderite to precipitate because $\mathrm{CO}_{2}$ storage and leakage would occur over much longer time scales than our experiments if geological carbon storage is implemented. Hence, minerals that form slowly may not have formed in our experiments but could be important over longer time scales in natural environments.

\subsection{Impact on water quality}

In contrast to the benefit of enhanced $\mathrm{CO}_{2}$ trapping, the elevated rate of $\mathrm{Fe}(\mathrm{III})$ reduction in the high- $\mathrm{CO}_{2}$ reactors negatively impacted water quality. The secondary water standard recommended by the U.S. EPA for Fe in drinking water is $5 \mu \mathrm{M}$. This level was easily exceeded in both sets of reactors (Fig. 1). The extent to which Fe(II) accumulated in solution was far greater, however, in the high- $\mathrm{CO}_{2}$ reactors.

Coupled with this impact, AVS measurements and mass-balance calculations show that an increased rate of Fe(III) reduction also led to lower abundances of goethite and solid-phase sulfide. Reflecting the balance between $\mathrm{Fe}(\mathrm{III})$ and $\mathrm{SO}_{4}{ }^{2-}$ reduction, the abundance of goethite and AVS was considerably lower in the high- $\mathrm{CO}_{2}$ reactors than the low- $\mathrm{CO}_{2}$ reactors at the end of the experiment. Our mass-balance calculations indicate that goethite content averaged $0.9 \mathrm{mmol}$ in the biologicallyactive low- $\mathrm{CO}_{2}$ reactors compared to only $0.5 \mathrm{mmol}$ in the biologically-active high- $\mathrm{CO}_{2}$ reactors at the end of the experiment. Similarly, AVS content averaged $35.7 \mu \mathrm{mol}$ in the biologically-active low$\mathrm{CO}_{2}$ reactors compared to only $1.4 \mu \mathrm{mol}$ in the biologically-active high- $\mathrm{CO}_{2}$ reactors (Fig. 6). The 
463 AVS that formed likely consisted of mackinawite $(\sim \mathrm{FeS})$, the precursor to pyrite in Fe-bearing, $\mathrm{SO}_{4}{ }^{2-}$

464 reducing environments (Berner, 1970).

465 These differences in mineralogy have the potential to affect water quality because both

466 solid-phases provide important sinks for many hazardous solutes in aqueous environments.

467 Arsenic, for example, can strongly sorb to iron oxides and oxyhydroxides or be sequestered by

468 sulfide minerals (Smedley and Kinniburgh, 2002). The $\mathrm{CO}_{2}$-induced shifts in microbiology that we

469 observed, therefore, favor enhance mobility of hazardous solutes such as arsenic.

470

\section{$471 \quad 3.6$. Implications for geological carbon storage}

Our findings imply that $\mathrm{CO}_{2}$ leakage into Fe-bearing anoxic aquifers can stimulate microbial

$473 \mathrm{Fe}(\mathrm{III})$ reduction. Where this occurs, $\mathrm{CO}_{2}$ trapping would be enhanced but water quality could

474 decrease. Because of these relationships, numerical simulations aiming to predict the long-term

475 behavior of $\mathrm{CO}_{2}$ leakage may underestimate the rate of $\mathrm{CO}_{2}$ trapping and the negative impact on

476 water quality if they do not account for microbial activity. Furthermore, these findings also imply

477 that $\mathrm{CO}_{2}$ leakage into an anoxic aquifer is less likely to reach the surface if $\mathrm{Fe}(\mathrm{III})$ and an active

478 microbial community are present.

479 Whether the results of this study also have implications for deep $\mathrm{CO}_{2}$ reservoirs is unclear.

480 The redox state of deep subsurface environments is often similar to that in our experiments, with

$481 \mathrm{Fe}(\mathrm{III}), \mathrm{SO}_{4}{ }^{2-}$, and inorganic carbon existing as the primary electron acceptors available (Bethke et

482 al., 2011; Lovley and Chapelle, 1995). Hence, a similar microbial feedback is possible. However, the

483 conditions would differ considerably from this experiment in terms of temperature, total pressure,

484 and salinity. The amount of $\mathrm{CO}_{2}$ the microbial community could be exposed to could also range to

485 much higher levels. Additional research is needed, therefore, to evaluate whether this feedback can

486 exist under conditions consistent with the deep subsurface. 


\section{CONCLUSIONS}

Our results demonstrate that the ability of $\mathrm{Fe}(\mathrm{III})$ reducers to compete with $\mathrm{SO}_{4}{ }^{2-}$ reducers was enhanced in reactors with high $\mathrm{CO}_{2}$ content. Whereas $\mathrm{SO}_{4}{ }^{2-}$ reducers accounted for most of the acetate consumption in the low- $\mathrm{CO}_{2}$ reactors, $\mathrm{Fe}(\mathrm{III})$ reducers were dominant in the high- $\mathrm{CO}_{2}$ reactors. Free energy calculations show that this shift may reflect variation in thermodynamic controls on microbial Fe(III) reduction. Physiological effects and $\mathrm{CO}_{2}$ toxicity may have also contributed to differences in microbial activity.

This shift in microbial activity impacted both carbon storage and water quality in the reactors. As a result of more rapid Fe(III) reduction, solubility trapping was enhanced and conditions were more favorable for siderite precipitation. Hence, the shift toward Fe(III) reduction that we observed at higher $\mathrm{CO}_{2}$ abundance represents a microbial feedback mechanism on $\mathrm{CO}_{2}$ trapping. However, the increased rate of Fe(III) reduction diminished water quality by greatly increasing Fe(II) concentration and led to lower abundances of goethite and solid-phase sulfide, solids that commonly serve as important sinks for hazardous solutes. Because the interactions between $\mathrm{CO}_{2}$ and microorganisms that we observed are possible in natural environments, accounting for microbial activity may improve the ability of numerical simulations to predict the fate and environmental impact of $\mathrm{CO}_{2}$ in the subsurface.

\section{ACKNOWLEDGEMENTS}

We are extremely grateful for laboratory support from Christopher Marry, Scot Dowd, Thomas Stewart, Andrew Miller, and Ernesto Tellez, helpful comments from Qusheng Jin, and a thorough manuscript review by Amy Halloran and three anonymous reviewers. This material is based upon work supported as part of the Center for Frontiers of Subsurface Energy Security, an Energy Frontier Research Center funded by the U.S. Department of Energy, Office of Science, Office of Basic Energy Sciences under Award Number DE-SC0001114. Sandia National Laboratories is a 
multi-program laboratory managed and operated by Sandia Corporation, a wholly owned

subsidiary of Lockheed Martin Corporation, for the U.S. Department of Energy's National Nuclear

Security Administration under contract DE-AC04-94AL85000.

\section{References}

Apps, J. A., Zheng, L., Zhang, Y., Xu, T., Birkholzer, J. T. (2010) Evaluation of potential changes in groundwater quality in response to $\mathrm{CO}_{2}$ leakage from deep geologic storage. Transport Porous Med. 82, 215-246.

Benson, S. M., Cole, D. R. (2008) $\mathrm{CO}_{2}$ sequestration in deep sedimentary formations. Elements 4, 325-331.

Benzerara, K., Miot, J., Morin, G., Ona-Nguema, G., Skouri-Panet, F., Ferard, C. (2011) Significance, mechanisms and environmental implications of microbial biomineralization. C. R. Geosci. 343, 160-167.

Berner, R. A. (1970) Sedimentary pyrite formation. Am. J. Sci. 268, 1-23.

Bertoloni, G., Bertucco, A., De Cian, V., Parton, T. (2006) A study on the inactivation of microorganisms and enzymes by high pressure $\mathrm{CO}_{2}$. Biotechnol. Bioeng. 95, 155-160.

Bethke, C. M., Sanford, R. A., Kirk, M. F., Jin, Q., Flynn, T. M. (2011) The thermodynamic ladder in geomicrobiology. Am. J. Sci. 311, 183-210.

Burch, S. L. (2008) Development of an Observation Well Network in the Mahomet Aquifer of EastCentral Illinois, Data/Case Study 2008-01. Illinois State Water Survey, Champaign, IL, p. 111.

Caporaso, J. G., Kuczynski, J., Stombaugh, J., Bittinger, K., Bushman, F. D., Costello, E. K., Fierer, N., Pena, A. G., Goodrich, J. K., Gordon, J. I., Huttley, G. A., Kelley, S. T., Knights, D., Koenig, J. E., Ley, R. E., Lozupone, C. A., McDonald, D., Muegge, B. D., Pirrung, M., Reeder, J., Sevinsky, J. R., Tumbaugh, P. J., Walters, W. A., Widmann, J., Yatsunenko, T., Zaneveld, J., Knight, R. (2010) QIIME allows analysis of high-throughput community sequencing data. Nat. Methods 7, 335336.

Celia, M. A., Nordbotten, J. M. (2009) Practical modeling approaches for geological storage of carbon dioxide. Ground Water 47, 627-638.

Delany, J. M., Lundeen, S. R. (1990) The LLNL thermochemical database, LLNL report UCRL-21658. Lawrence Livermore National Laboratory.

Dowd, S. E., Callaway, T. R., Wolcott, R. D., Sun, Y., McKeehan, T., Hagevoort, R. G., Edrington, T. S. (2008) Evaluation of the bacterial diversity in the feces of cattle using $16 \mathrm{~S}$ rDNA bacterial tag-encoded FLX amplicon pyrosequencing (bTEFAP). BMC Microbiol. 8.

Eaton, A. D., Clesceri, L. S., Greenberg, A. E. (1995) Standard Methods for the Examination of Water and Wastewater, 19 ed. American Public Health Association, American Water Works Association, and Water Environmental Federation, Washington, DC USA.

Edgar, R. C. (2010) Search and clustering orders of magnitude faster than BLAST. Bioinformatics 26, 2460-2461.

Flynn, T. M., Sanford, R. A., Bethke, C. M. (2008) Attached and suspended microbial communities in a pristine confined aquifer. Wat. Resour. Res. 44, 1-7.

Flynn, T. M., Sanford, R. A., Ryu, H., Bethke, C. M., Levine, A. D., Ashbolt, N. J., Santo Domingo, J. W. (2013) Functional microbial diversity explains groundwater chemistry in a pristine aquifer. BMC Microbiol. 13.

Flynn, T. M., Sanford, R. A., Santo Domingo, J. W., Ashbolt, N. J., Levine, A. D., Bethke, C. M. (2012) The active bacterial community in a pristine confined aquifer. Wat. Resour. Res. 48, W09510. 
602

603

604

605

606

Garrity, G. M., Brenner, D. J., Krieg, N. R., Staley, J. T. (2005) The Alpha-, Beta-, Delta-, and Epsilonproteobacteria, Bergey's Manual of Systematic Bacteriology. Springer, New York.

Gerlach, R., Cunningham, A. B. (2010) Influence of Biofilms on Porous Media Hydrodynamics, in: Vafai, K. (Ed.), Porous Media: Applications in Biological Systems and Biotechnology. CFC Press, New York, pp. 173-230.

Harvey, O. R., Qafoku, N. P., Cantrell, K. J., Lee, G., Amonette, J. E., Brown, C. F. (2013) Geochemical implications of gas leakage associated with geological $\mathrm{CO}_{2}$ storage - a qualitative review. Environ. Sci. Technol. 47, 23-36.

Helgeson, H. C. (1969) Thermodynamics of hydrothermal systems at elevated temperatures and pressures. Am. J. Sci. 267, 729-804.

Inagaki, F., Kuypers, M. M. M., Tsunogai, U., Ishibashi, J., Nakamura, K., Treude, T., Ohkubo, S., Nakaseama, M., Gena, K., Chiba, H., Hirayama, H., Nunoura, T., Takai, K., Jorgensen, B. B., Horikoshi, K., Boetius, A. (2006) Microbial community in a sediment-hosted $\mathrm{CO}_{2}$ lake of the southern Okinawa Trough hydrothermal system. P. Natl. Acad. Sci. USA 103, 14164-14169.

IPCC (2005) Special Report on Carbon Capture and Storage. Available at http://www.ipcc.ch/.

Jimenez-Lopez, C., Romanek, C. S. (2004) Precipitation kinetics and carbon isotope partitioning of inorganic siderite at $25^{\circ} \mathrm{C}$ and 1 atm. Geochim. Cosmochim. Acta 68, 557-571.

Jin, Q., Bethke, C. M. (2002) Kinetics of electron transfer through the respiratory chain. Biophys. J. 83, 1797-1808.

Jin, Q., Bethke, C. M. (2003) A new rate law describing microbial respiration. Appl. Environ. Microbiol. 69, 2340-2348.

Jin, Q., Bethke, C. M. (2005) Predicting the rate of microbial respiration in geochemical environments. Geochim. Cosmochim. Acta 69, 1133-1143.

Jin, Q., Bethke, C. M. (2007) The thermodynamics and kinetics of microbial metabolism. Am. J. Sci. 307, 643-677.

Jin, Q., Bethke, C. M. (2009) Cellular energy conservation and the rate of microbial sulfate reduction. Geology 37, 1027-1030.

Kelly, W. R., Holm, T. R., Wilson, S. D., Roadcap, G. S. (2005) Arsenic in glacial aquifers: sources and geochemical controls. Ground Water 43, 500-510.

Kempton, J. P., Johnson, W. H., Heigold, P. C., Cartwright, K. (1991) Mahomet Bedrock Valley in eastcentral Illinois; Topography, glacial drift stratigraphy, and hydrogeology, in: Melhorn, W.N., Kempton, J.P. (Eds.), Geology and hydrogeology of the Teays-Mahomet Bedrock Valley System. Geological Society of America Special Paper 258, pp. 91-124.

Kharaka, Y. K., Thordsen, J. J., Kakouros, E., Ambats, G., Herkelrath, W. N., Beers, S. R., Birkholzer, J. T., Apps, J. A., Spycher, N. F., Zheng, L. E., Trautz, R. C., Rauch, H. W., Gullickson, K. S. (2010) Changes in the chemistry of shallow groundwater related to the 2008 injection of $\mathrm{CO}_{2}$ at the ZERT field site, Bozeman, Montana. Environ. Earth Sci. 60, 273-284.

Kirk, M. F. (2011) Variation in energy available to populations of subsurface anaerobes in response to geological carbon storage. Environ. Sci. Technol. 45, 6676-6682.

Kirk, M. F., Roden, E. E., Crossey, L. J., Brearley, A. J., Spilde, M. N. (2010) Experimental analysis of arsenic precipitation during microbial sulfate and iron reduction in model aquifer sediment reactors. Geochim. Cosmochim. Acta 74, 2538-2555.

Little, M. G., Jackson, R. B. (2010) Potential impacts of leakage from deep $\mathrm{CO}_{2}$ geosequestration on overlying freshwater aquifers. Environ. Sci. Technol. 44, 9225-9232.

Lonergan, D. J., Jenter, H. L., Coates, J. D., Phillips, E. J. P., Schmidt, T. M., Lovley, D. R. (1996) Phylogenetic analysis of dissimilatory Fe(III)-reducing bacteria. J. Bacteriol. 178, 24022408.

Lovley, D. R. (2001) Bioremediation - Anaerobes to the rescue. Science 293, 1444-1446.

Lovley, D. R., Chapelle, F. H. (1995) Deep subsurface microbial processes. Rev. Geophys. 33, 365-381. 
Lu, J. M., Partin, J. W., Hovorka, S. D., Wong, C. (2010) Potential risks to freshwater resources as a result of leakage from $\mathrm{CO}_{2}$ geological storage: a batch-reaction experiment. Environ. Earth Sci. 60, 335-348.

Madigan, M. T., Martinko, J. M., Parker, J. (2003) Brock Biology of Microorganisms, 10 ed. Pearson Education, Inc., Upper Saddle River.

McMahon, P. B., Chapelle, F. H. (1991) Microbial production of organic acids in aquitard sediments and its role in aquifer geochemistry. Nature 349, 233-235.

Mitchell, A. C., Phillips, A. J., Hamilton, M. A., Gerlach, R., Hollis, W. K., Kaszuba, J. P., Cunningham, A. B. (2008) Resilience of planktonic and biofilm cultures to supercritical $\mathrm{CO}_{2}$. J. Supercrit. Fluids 47, 318-325.

Oppermann, B. I., Michaelis, W., Blumenberg, M., Frerichs, J., Schulz, H. M., Schippers, A., Beaubien, S. E., Kruger, M. (2010) Soil microbial community changes as a result of long-term exposure to a natural $\mathrm{CO}_{2}$ vent. Geochim. Cosmochim. Acta 74, 2697-2716.

Oule, M. K., Tano, K., Bernier, A. M., Arul, J. (2006) Escherichia coli inactivation mechanism by pressurized $\mathrm{CO}_{2}$. Can. J. Microbiol. 52, 1208-1217.

Petrie, L., North, N. N., Dollhopf, S. L., Balkwill, D. L., Kostka, J. E. (2003) Enumeration and characterization of iron(III)-reducing microbial communities from acidic subsurface sediments contaminated with uranium(VI). Appl. Environ. Microbiol. 69, 7467-7479.

Postma, D., Jakobsen, R. (1996) Redox zonation: Equilibrium constraints on the Fe(III)/SO $\mathrm{SO}_{4}$ reduction interface. Geochim. Cosmochim. Acta 60, 3169-3175.

Quince, C., Lanzen, A., Davenport, R. J., Turnbaugh, P. J. (2011) Removing noise from pyrosequenced amplicons. BMC Bioinformatics 12.

Santillan, E. U., Kirk, M. F., Altman, S. J., Bennett, P. C. (2013) Mineral influence on microbial survival during carbon sequestration. Geomicrobiol. J. 30, 578-592.

Smedley, P. L., Kinniburgh, D. G. (2002) A review of the source, behaviour, and distribution of arsenic in natural waters. Appl. Geochem. 17, 517-568.

Stookey, L. L. (1970) Ferrozine - a new spectrophotometric reagent for iron. Anal. Chem. 42, 779781.

Thomas, S. H., Padilla-Crespo, E., Jardine, P. M., Sanford, R. A., Loffler, F. E. (2009) Diversity and distribution of Anaeromyxobacter strains in a uranium-contaminated subsurface environment with a nonuniform groundwater flow. Appl. Environ. Microbiol. 75, 3679-3687.

Treude, N., Rosencrantz, D., Liesack, W., Schnell, S. (2003) Strain FAc12, a dissimilatory ironreducing member of the Anaeromyxobacter subgroup of Myxococcales. FEMS Microbiol. Ecol. 44, 261-269.

Uroz, S., Calvaruso, C., Turpault, M. P., Frey-Klett, P. (2009) Mineral weathering by bacteria: ecology, actors and mechanisms. Trends Microbiol. 17, 378-387.

Videmsek, U., Hagn, A., Suhadolc, M., Radl, V., Knicker, H., Schloter, M., Vodnik, D. (2009) Abundance and diversity of $\mathrm{CO}_{2}$-fixing bacteria in grassland soils close to natural carbon dioxide springs. Microb. Ecol. 58, 1-9.

Wang, Q., Garrity, G. M., Tiedje, J. M., Cole, J. R. (2007) Naive Bayesian classifier for rapid assignment of rRNA sequences into the new bacterial taxonomy. Appl. Environ. Microbiol. 73, 52615267.

Wang, S., Jaffe, P. R. (2004) Dissolution of a mineral phase in potable aquifers due to $\mathrm{CO}_{2}$ releases from deep formations; effect of dissolution kinetics. Energ. Convers. Manage. 45, 2833-2848.

Wilkin, R. T., Digiulio, D. C. (2010) Geochemical impacts to groundwater from geologic carbon sequestration: Controls on $\mathrm{pH}$ and inorganic carbon concentrations from reaction path and kinetic modeling. Environ. Sci. Technol. 44, 4821-4827.

Wimmer, Z., Zarevucka, M. (2010) A review on the effects of supercritical carbon dioxide on enzyme activity. Int. J. Mol. Sci. 11, 233-253. 
Wu, B., Shao, H. B., Wang, Z. P., Hu, Y. D., Tang, Y. J. J., Jun, Y. S. (2010) Viability and metal reduction of Shewanella oneidensis MR-1 under $\mathrm{CO}_{2}$ stress: Implications for ecological effects of $\mathrm{CO}_{2}$ leakage from geologic $\mathrm{CO}_{2}$ sequestration. Environ. Sci. Technol. 44, 9213-9218.

Yakimov, M. M., Giuliano, L., Crisafi, E., Chernikova, T. N., Timmis, K. N., Golyshin, P. N. (2002) Microbial community of a saline mud volcano at San Biagio-Belpasso, Mt. Etna (Italy). Environ. Microbiol. 4, 249-256.

Zhang, J., Davis, T. A., Matthews, M. A., Drews, M. J., LaBerge, M., An, Y. H. H. (2006) Sterilization using high-pressure carbon dioxide. 38, 354-372.

Zheng, L. G., Apps, J. A., Zhang, Y. Q., Xu, T. F., Birkholzer, J. T. (2009) On mobilization of lead and arsenic in groundwater in response to $\mathrm{CO}_{2}$ leakage from deep geological storage. Chem. Geol. 268, 281-297. 
Figure Captions

$670 \quad$ Figure 1
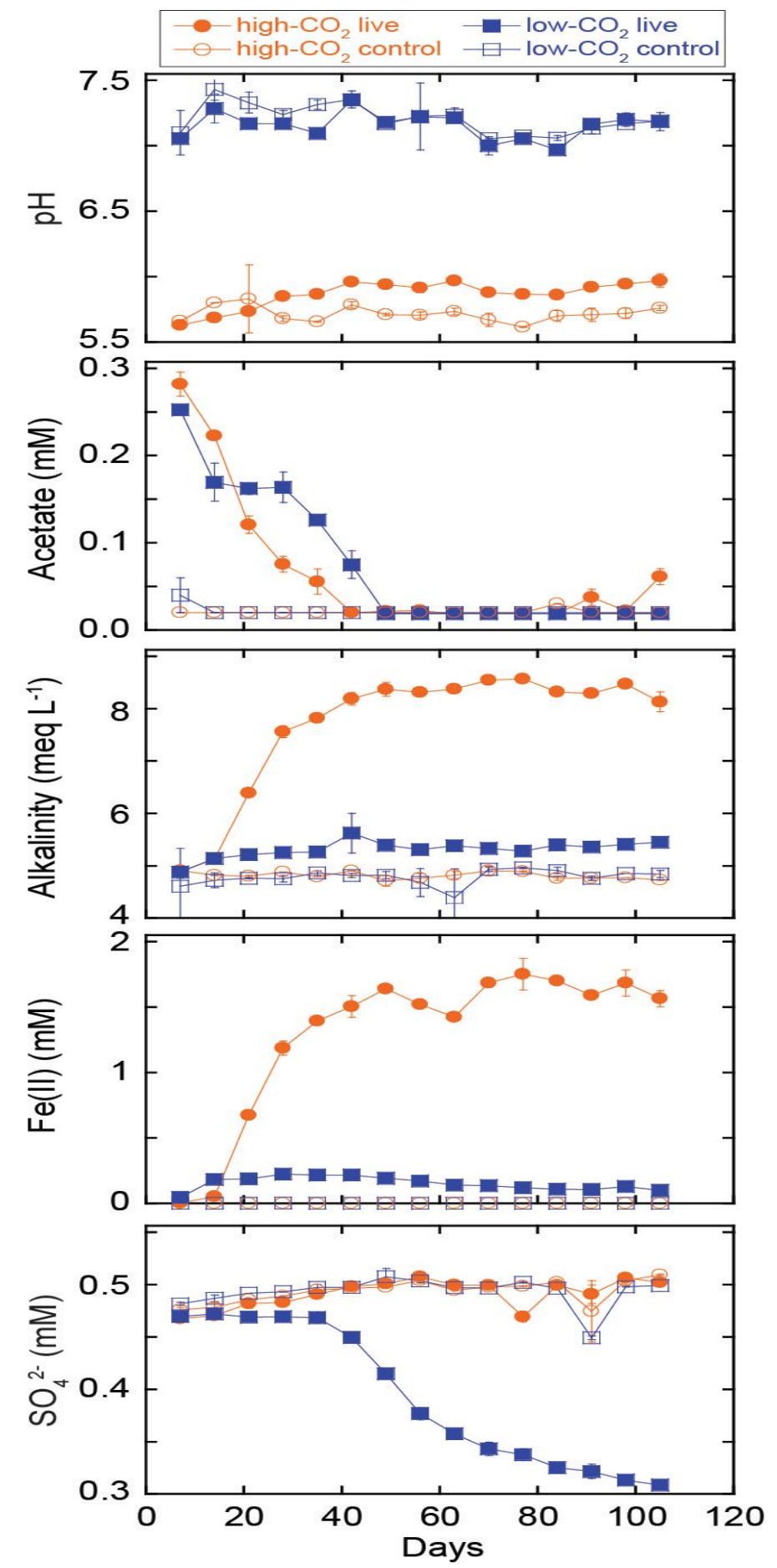
672 Figure 1. Variation in the $\mathrm{pH}$, acetate, alkalinity, $\mathrm{Fe}(\mathrm{II})$, and $\mathrm{SO}_{4}{ }^{2-}$ content of effluent from the high- and low-

$673 \mathrm{CO}_{2}$ reactors during the experiment. Control reactors were not biologically active. Each data point shows the

674 median of values measured in duplicate reactors and error bars show the range in values for those duplicates.

675 Detection limits are plotted for values determined to be below method detection limits. Note that the y-axis

676 origin is not zero for graphs showing $\mathrm{pH}$, alkalinity, and $\mathrm{SO}_{4}^{2-}$ data.

677 Figure 2
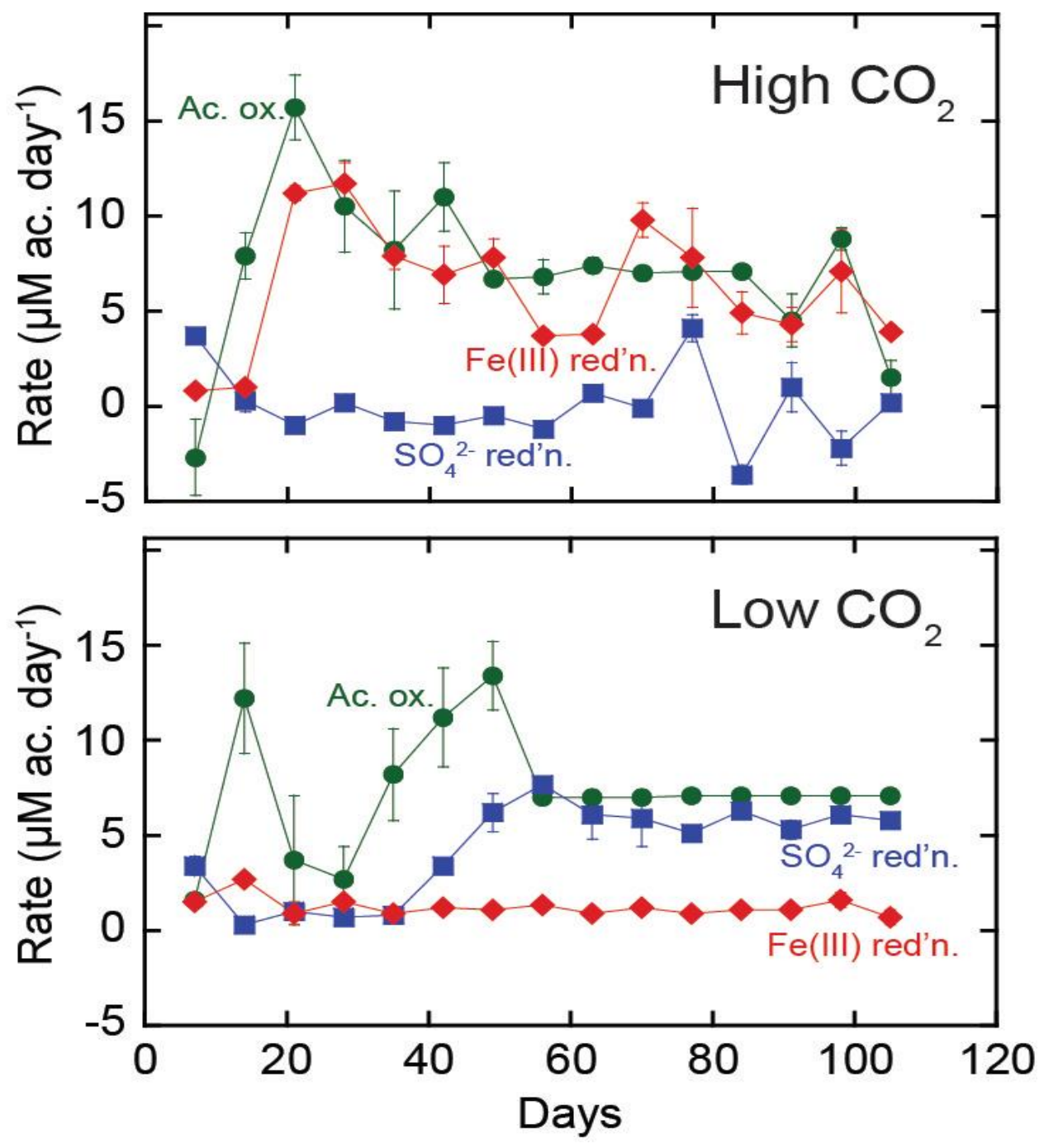

679

Figure 2. Variation in the overall rate of acetate oxidation and the rate of acetate oxidation by $\mathrm{Fe}(\mathrm{III})$ and $\mathrm{SO}_{4}{ }^{2-}$

681 reducers in the high- and low- $\mathrm{CO}_{2}$ reactors during the experiment. Each data point shows the median value

682 calculated for duplicate reactors and error bars show the range in values for those duplicates. 

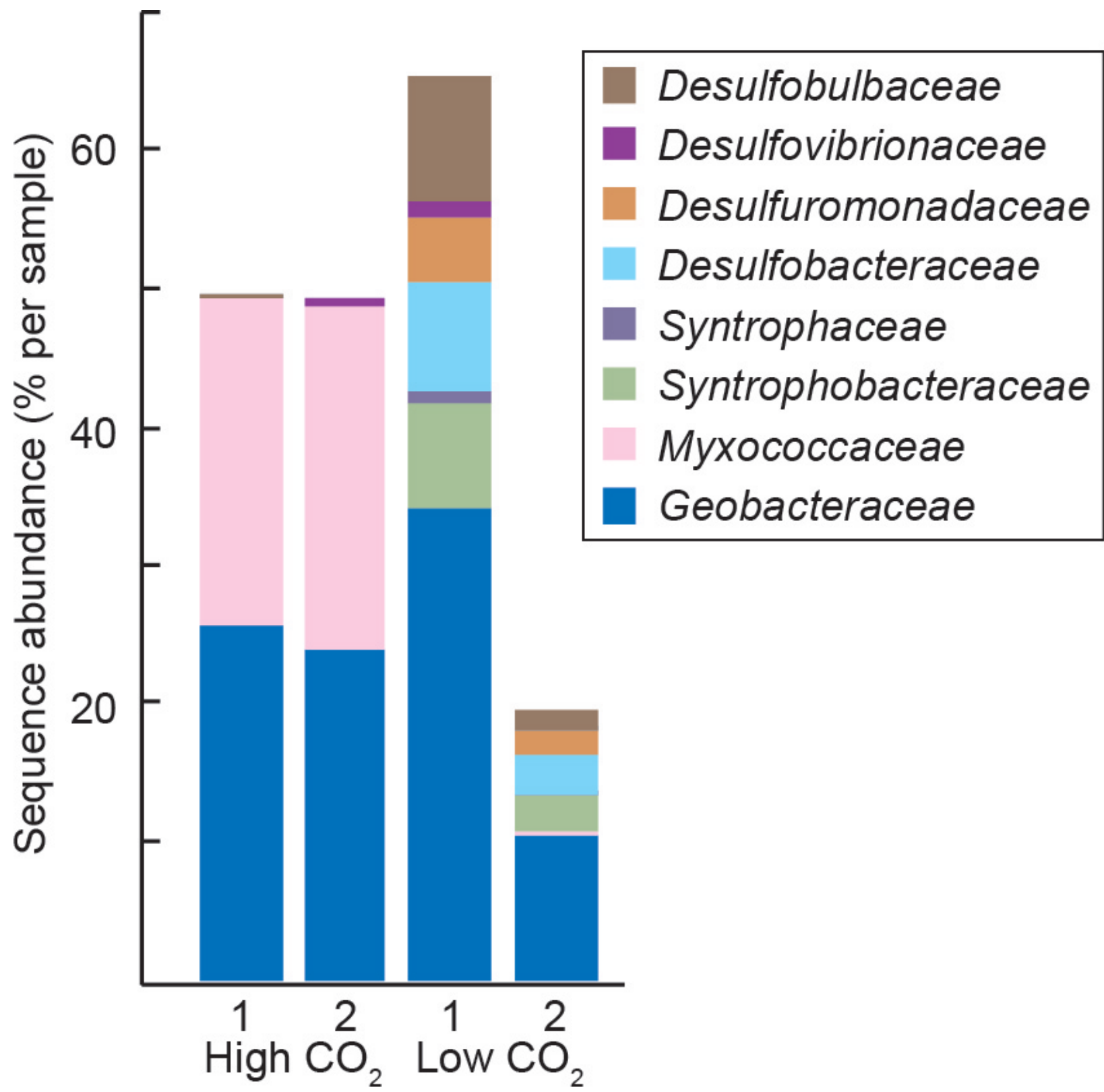

685 Figure 3. Taxonomic distribution of sequences grouping within the $\delta$-Proteobacteria. Results are shown

686 individually for each duplicate biologically-active reactor. Taxonomy was evaluated at an $80 \%$ confidence

687 threshold. An OTU heatmap showing a broader range of taxa than this figure is available in the Electronic 688 Annex (Figure EA2). 


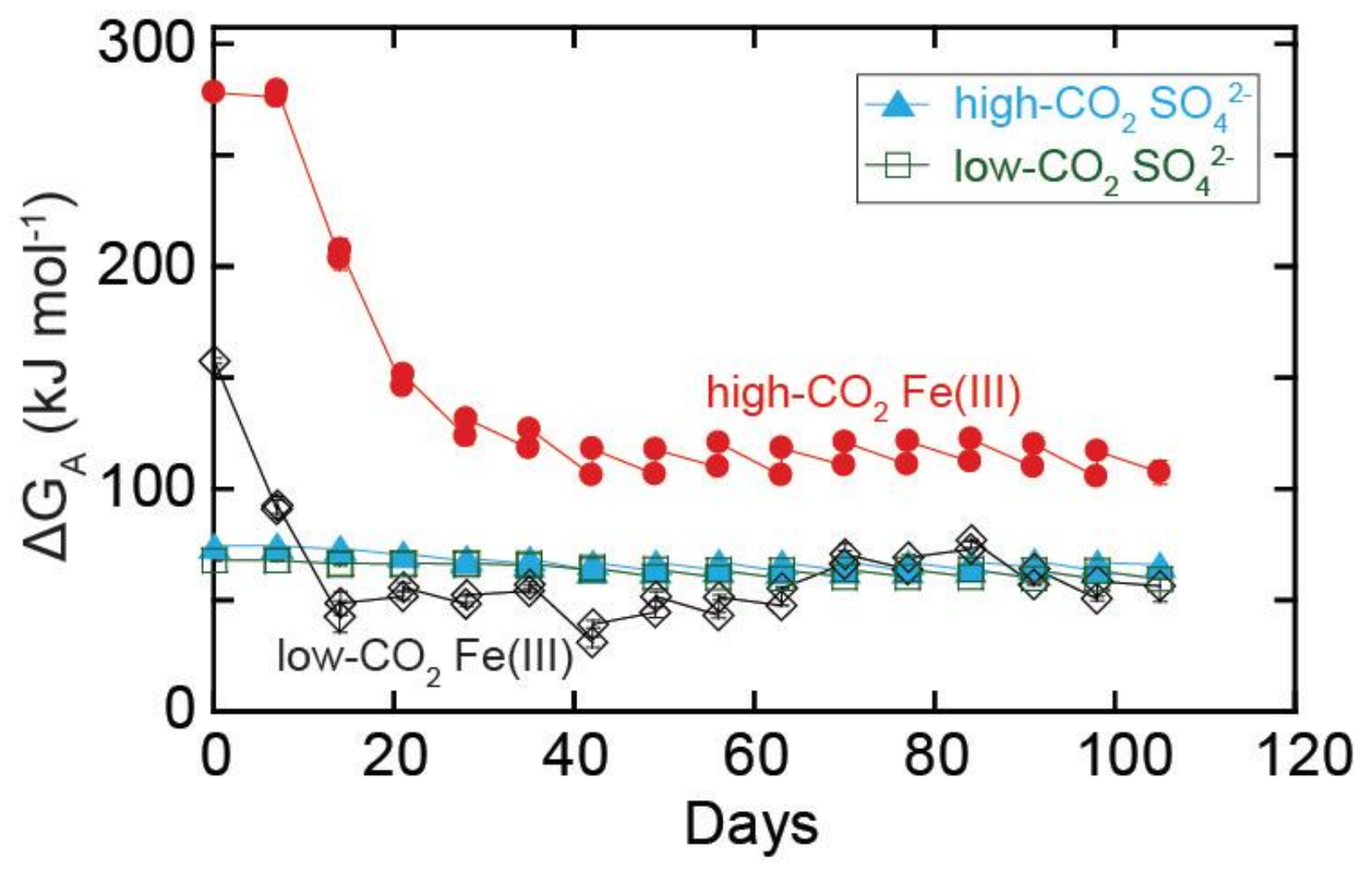

692

693 Figure 4. Energy available $\left(\Delta G_{A}\right)$ for acetate oxidation coupled to $\mathrm{Fe}(\mathrm{III})$ and $\mathrm{SO}_{4}{ }^{2-}$ reduction in the high and 694 low- $\mathrm{CO}_{2}$ reactors at the beginning and end of each week. Each data point shows the median value calculated 695 for duplicate reactors. The error bars show the range in values for those duplicates. 
Figure 5
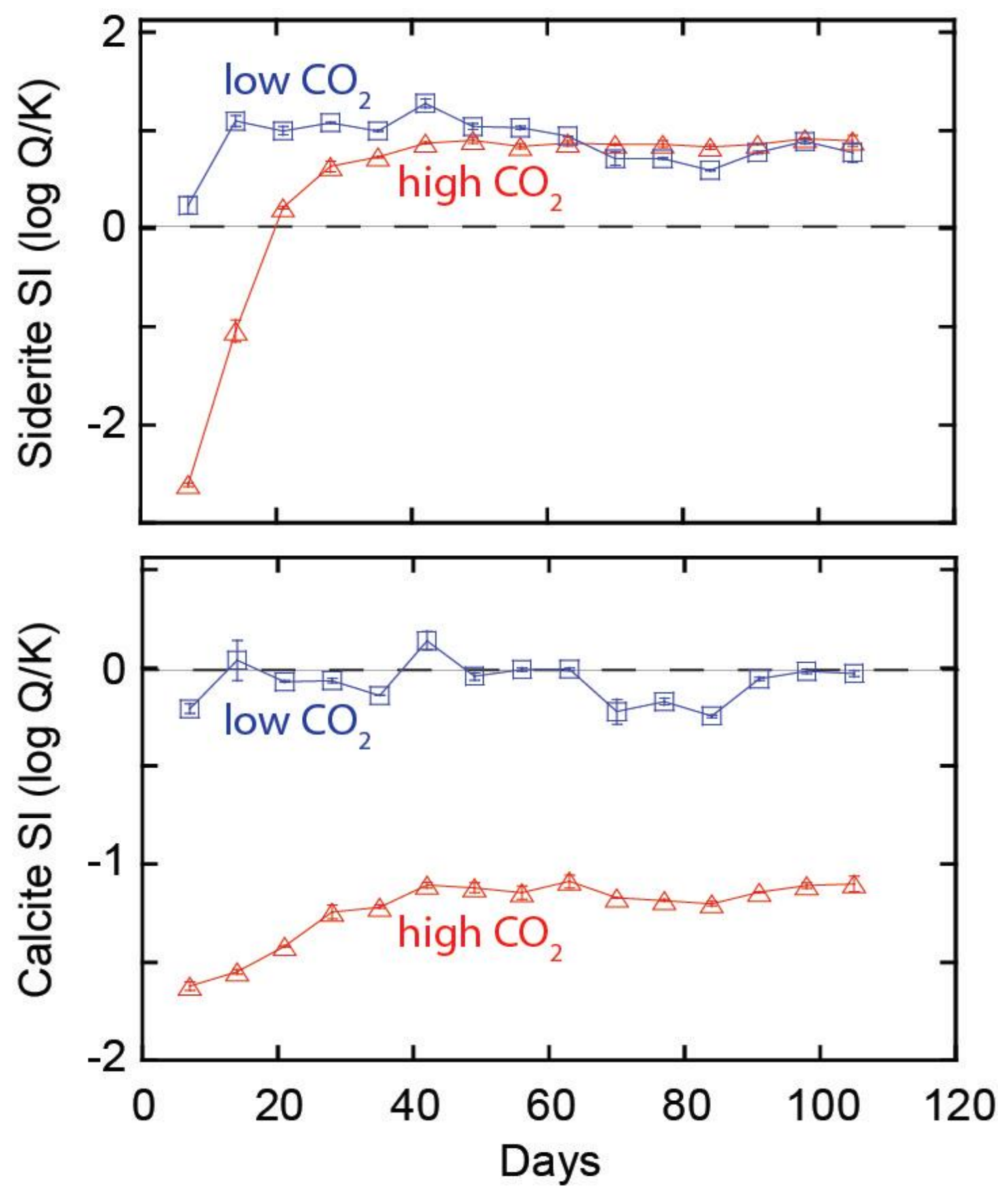

699 Figure 5. Variation in the saturation index $(\mathrm{SI})$ of siderite $\left(\mathrm{FeCO}_{3}\right)$ and calcite $\left(\mathrm{CaCO}_{3}\right)$ in the biologically-active

700 high-and low- $\mathrm{CO}_{2}$ reactors based on chemical analysis of effluent. Each data point shows the median value

701 calculated for duplicate reactors. The error bars show the range in values for those duplicates. Precipitation of a mineral is thermodynamically favorable where $\log (\mathrm{Q} / \mathrm{K})$ values are $>0$. 


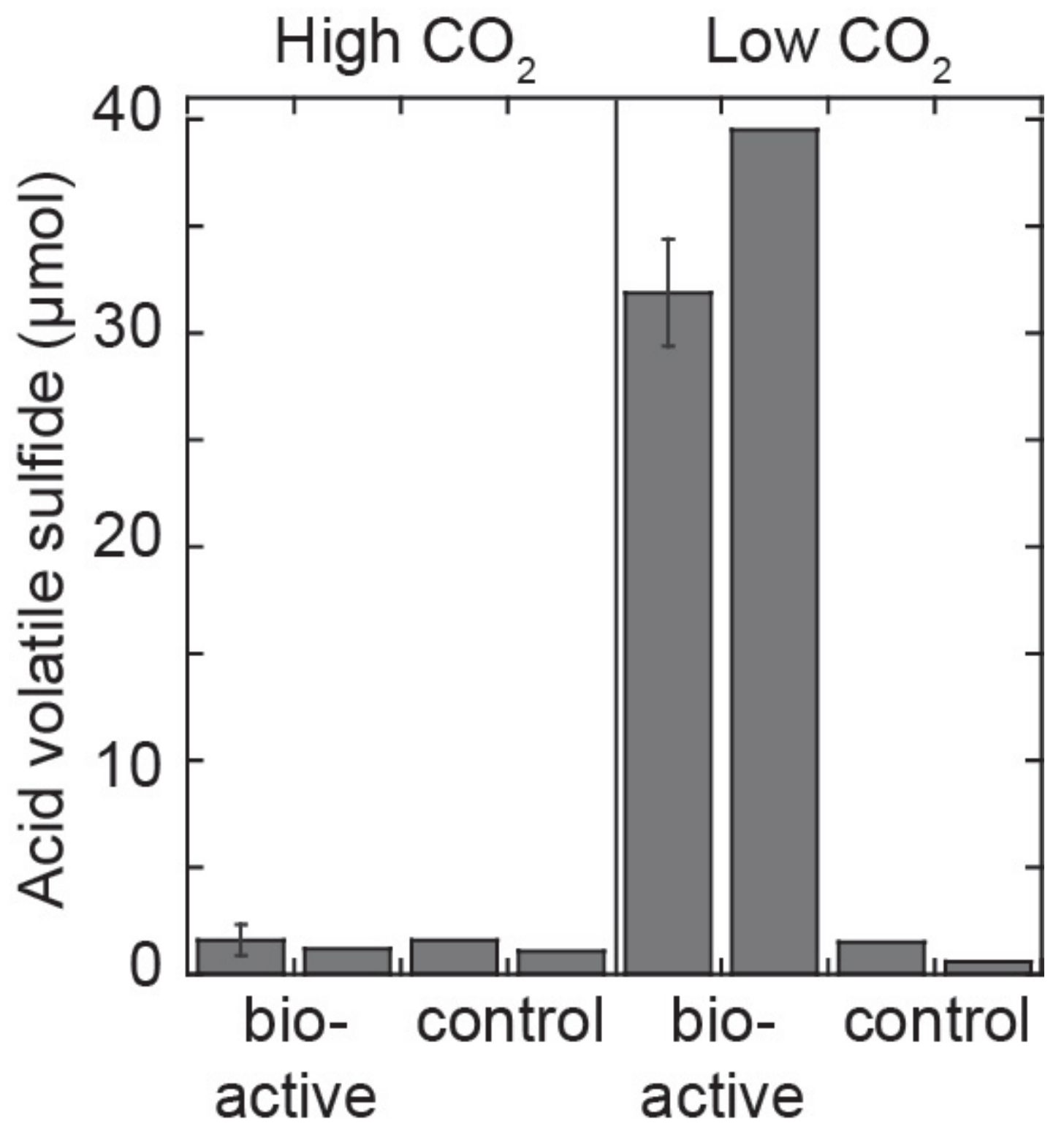

706 Figure 6. Acid volatile sulfide (AVS) content of each reactor at the end of the experiment. Results are shown

707 individually for each duplicate reactor. Mean values and error bars corresponding to standard deviation are

708 provided for extractions performed in triplicate (one high- $\mathrm{CO}_{2}$ and one low- $\mathrm{CO}_{2}$ reactor). 